\title{
Application of polymeric materials for obtaining gears with involute and sinusoidal profile (Rapid communication)
}

\author{
Mariusz Sobolak $^{1), *)}$, Piotr Połowniak ${ }^{1)}$, Mariusz Cieplak ${ }^{1)}$, Mariusz Oleksy ${ }^{2)}$, Katarzyna Bulanda ${ }^{2)}$ \\ DOI: dx.doi.org/10.14314/polimery.2020.7.9
}

\begin{abstract}
In the article research related to the increasing in the scope of application of additive technologies in the construction of machines for the production of gears with involute and sinusoidal profile from polymeric materials was presented. The designed original research stand and with its use carried out a series of preliminary fatigue tests of the obtained polymer gears with an involute and sinusoidal profile was show. The tested gears were obtained in the technology of rapid prototyping by the FFF (Fused Filament Fabrication) method from polymer composites obtained in the form of an ABS (acrylonitrile/butadiene/styrene) - based filament. Based on the results obtained, it was noticed that the temperature in the meshing zone of the gears with involute profiles is higher than for sinusoidal profiles, regardless of the type of composite from which the gears were made. It should also be noted that in the range of nominal load, the sound intensity level of the meshing zone is also lower for gears with a sinusoidal profile than for gears with an involute profile. Based on the tests carried out, an increase in sound intensity was noticed in the case of gears obtained from selected composites (Table 2) compared to the gear obtained from unfilled ABS. However, in the case of gears obtained from the tested composite materials, we observe a decrease in the gear operating temperature (Table 2). The most favorable results of these tests were obtained for gears with a sinusoidal profile obtained from ABS + P2 composite, which show the lowest operating temperature of the gear. It should also be mentioned that slightly worse results were obtained for involute gears.
\end{abstract}

Keywords: polymer materials, polymer machine elements, FFF (Fused Filament Fabrication) additive technologies, gears with involute and sinusoidal profile.

\section{Zastosowanie materiałów polimerowych do otrzymywania przekładni zębatych o zarysie ewolwentowym i sinusoidalnym}

Streszczenie: Przedstawiono badania związane ze zwiększeniem zakresu zastosowania technologii przyrostowych w budowie maszyn do otrzymywania przekładni zębatych o zarysie ewolwentowym i sinusoidalnym, które mogą być wytwarzane z materiałów polimerowych z wykorzystaniem technologii przyrostowych. Opisano zaprojektowane autorskie stanowisko badawcze, na którym przeprowadzono serię wstępnych badań zmęczeniowych przekładni zębatych o zarysie ewolwentowym i sinusoidalnym, otrzymanych z materiałów polimerowych. Badane przekładnie zębate wytworzono za pomocą technologii szybkiego prototypowania (FFF) z kompozytów polimerowych na osnowie z ABS (akrylonitryl/butadien/styren) w postaci filamentów. Na podstawie uzyskanych wyników badań stwierdzono, że temperatura kół o zarysie ewolwentowym w strefie zazębiania jest wyższa niż kół o zarysie sinusoidalnym, niezależnie od rodzaju kompozytu, z którego wykonano koła zębate, a w zakresie obciążenia nominalnego także poziom natężenia dźwięku emitowanego w strefie zazębiania jest wyższy w wypadku kół o zarysie ewolwentowym niż kół o zarysie sinusoidalnym. Zaobserwowano nieznaczny wzrost natężenia generowanego dźwięku w wypadku przekładni zębatych otrzymanych z wytypowanych kompozytów (tabela 2) w porównaniu z natężeniem dźwięku generowanego przez przekładnię wykonaną z nienapełnionego ABS. W odniesieniu do przekładni otrzymanych z badanych materiałów kompozytowych zaobserwowano spadek temperatury pracy przekładni (tabela 2). Najniższą tempe-

\footnotetext{
1) Faculty of Mechanical Engineering and Aeronautics, Rzeszow University of Technology, al. Powstańców Warszawy 12, 35-959 Rzeszów, Poland.

2) Faculty of Chemistry, Rzeszow University of Technology, al. Powstańców Warszawy 12, 35-959 Rzeszów, Poland.

*) Author for correspondence: msobolak@prz.edu.pl
} 
raturę pracy wykazywała przekładnia kół zębatych o zarysie sinusoidalnym otrzymana z kompozytu ABS + P2, a tylko nieznacznie gorsze wyniki uzyskano w wypadku przekładni kół zębatych o zarysie ewolwentowym

Słowa kluczowe: materiały polimerowe, polimerowe elementy maszyn, technologia przyrostowa FFF (Fused Filament Fabrication), przekładnie zębate o zarysie ewolwentowym i sinusoidalnym.

Gears in which wheels are made of polymer materials are often found in various household appliances: grinders, mixers, food processor, juice squeezers, etc. They are also used in the electromechanical and automotive industries [1-5]. In many cases, they have replaced traditional metal gears. Often the gears used in the above devices are made in the likeness of metal gears, in which the involute tooth profile is most often used. Such an profile has many advantages, such as being insensitive to a slight shift of the gears axle. However, it is recommended that gears made of polymeric materials have greater circumferential clearance. This is due to the fact that, unlike steel gears, the teeth bend during operation. This deflection can cause the gearing to jam when the peripheral clearances are too small, as well as increase the noise and thus accelerated gear wear. Currently, the aim is, especially in home appliances, to reduce the noise emitted by the gear in order to increase the comfort of using the devices. And also to reduce the amount of heat generated during gear operation due to the properties of polimer materials used that are not resistant to high temperatures. The article presents the results of fatigue tests of gears obtained from selected polymer materials with involute and sinusoidal profile (Fig. 1).

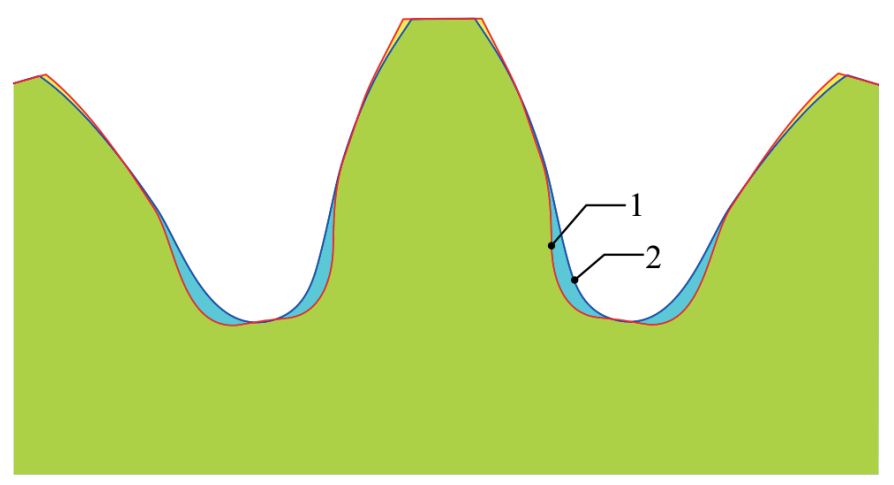

Fig. 1. Comparison of profiles on a gear segment: 1 - involute profile (red line), 2 - sinusoidal profile (blue line)

\section{EXPERIMENTAL PART}

\section{Materials}

ABS-M30 (producer DAEMON 3D Print) was used as the polymer matrix, and the selected fillers are dust with a grain size less than $0.06 \mathrm{~mm}$ bronze (P1), copper (P2), and brass (P3).

\section{Preparation of the composites}

Polymer materials were obtained after mixing together appropriate amounts of components: 79.5 parts by weight ABS, 20 parts by weight metal dust and 0.5 parts by weight compatibilizer. Mixing of ABS with the selected metallic dust was carried out using a Cooperion twin screw extruder with the following parameters: 400 screw revolutions/min, extrusion efficiency equal to $4 \mathrm{~kg} / \mathrm{h}$ and in the temperature range from $230^{\circ} \mathrm{C}$ to $240^{\circ} \mathrm{C}$.

\section{Preparation of the test samples}

From the obtained composites, filaments with a diameter of $2.85 \pm 0.05 \mathrm{~mm}$ were used for printing in FFF technology on a proprietary filament production line spe-

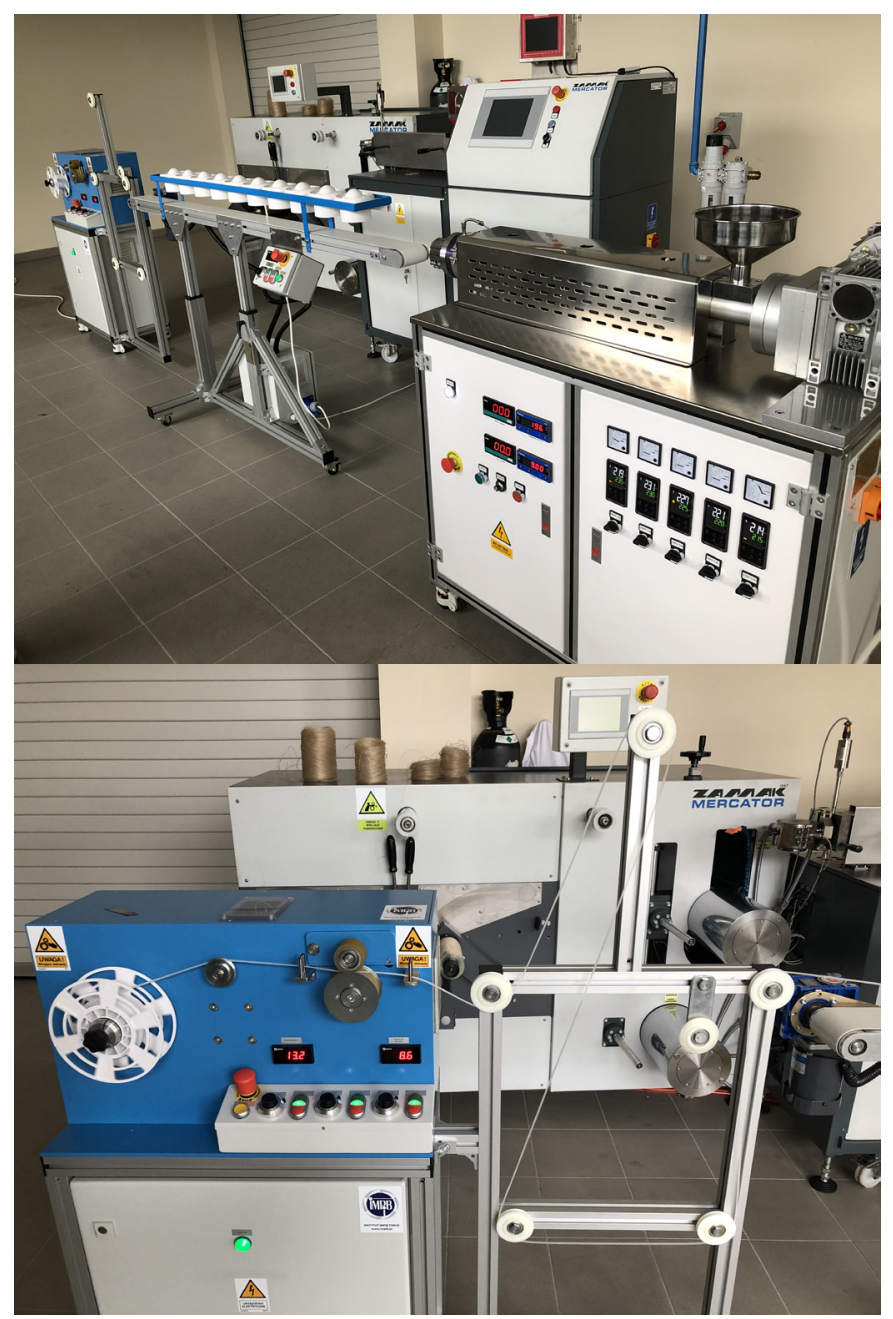

Fig. 2. Original filament production line designed as part of the work 


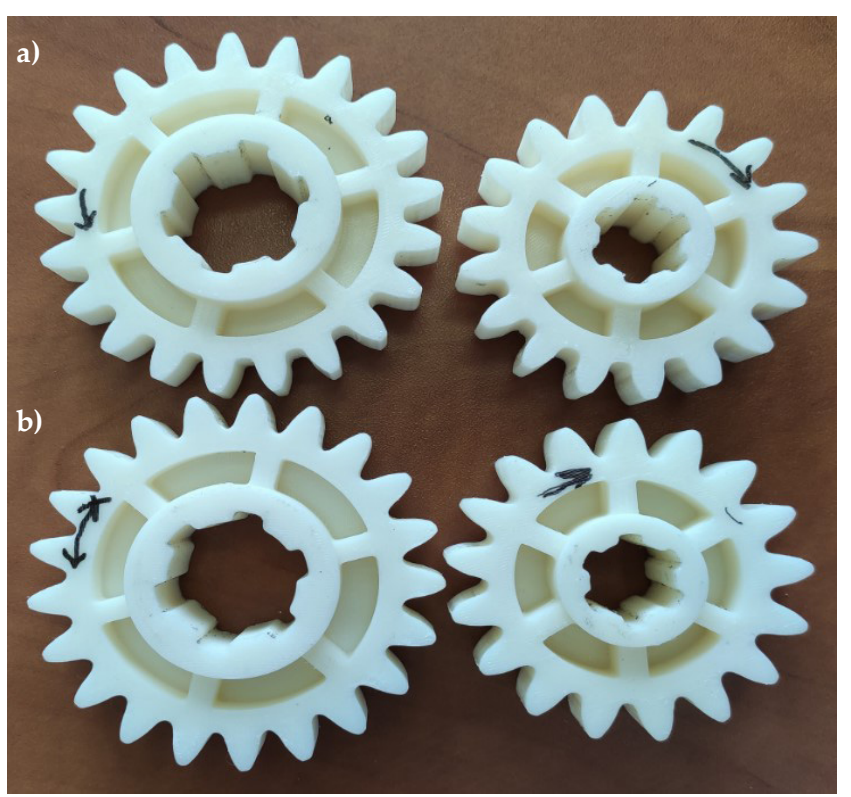

Fig. 3. Test models of gears for fatigue tests with: a) involute profile, b) sinusoidal profile

cially designed and obtained by METACHEM in Torun (Fig. 2) in the extrusion temperature range $215^{\circ} \mathrm{C}$ up to $230^{\circ} \mathrm{C}$.

The test samples, the view of which is shown in Fig. 3, were obtained using the PRUS MK3 machine working in the FFF method with the following process parameters: $45^{\circ}$ filling angle, $100 \%$ filling density, $0.2 \mathrm{~mm}$ layer height, extruder speed $70 \mathrm{~mm} / \mathrm{s}$, extrusion temperature $240^{\circ} \mathrm{C}$, working platform temperature $70^{\circ} \mathrm{C}$.

\section{Methods of testing}

\section{Stand fatigue tests of gears loaded with torsional} moment

Stand tests were carried out at the Department of Mechanical Engineering at the Faculty of Mechanical Engineering and Aeronautics at the Rzeszow University of Technology. The parameters of the developed test cycle

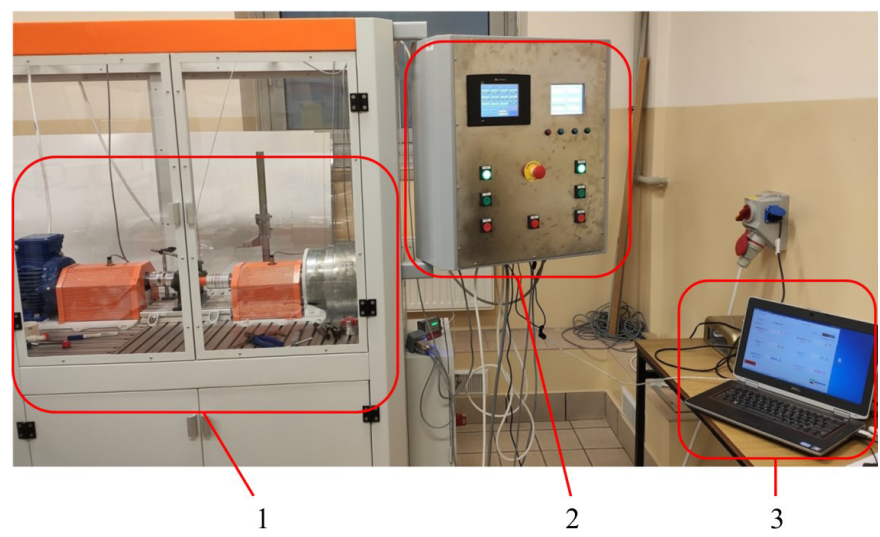

Fig. 4. Test stand for testing gears made of polymeric materials: 1 - test chamber, 2 - programming and control system, 3 - recording computer
T a b l e 1. Parameters of the cycle of fatigue tests of tested gears

\begin{tabular}{|c|c|c|c|c|}
\hline & \multicolumn{4}{|c|}{ Load cycle } \\
\hline & A & B & $\mathrm{C}$ & $\mathrm{D}$ \\
\hline $\begin{array}{l}\text { Turnover } n_{1} \\
\text { rpm }\end{array}$ & 500 & 500 & 500 & 500 \\
\hline $\begin{array}{c}\text { Torque } T_{1} \\
\text { Nm }\end{array}$ & 2.5 & 3.0 & 3.5 & 4.0 \\
\hline $\begin{array}{l}\text { Cycle time } \\
\text { min }\end{array}$ & 25 & 15 & 15 & 15 \\
\hline
\end{tabular}

program are summarized in Table 1 . This program consists of four $\mathrm{A} \div \mathrm{D}$ cycles for which the braking torque was changed in the range from $2.5 \mathrm{Nm}$ to $4 \mathrm{Nm}$ every $0.5 \mathrm{Nm}$. It should be noted that the $3 \mathrm{Nm}$ torque is the nominal moment for this gear. In cycle $\mathrm{A}$, the gear operation time was increased to 25 minutes for gradual gear arrangement. In cycles $C$ and $D$, the gear has been intentionally overloaded.

Figure 4 and Fig. 5 show the station for fatigue testing of gears.

\section{RESULTS AND DISCUSSION}

In order to carry out tests of fatigue resistance of tested involute and sinusoidal gears (Fig. 1), a concept of a test stand was developed that would allow loading samples and recording test results (temperature and sound intensity depending on the moment of load) (Fig. 5). The tests were carried out to determine the set parameters loaded with the torsional moment according to the previously developed and published methodology [6]. The tests carried out on samples made using the FFF method allowed the determination of changes in temperature and sound intensity values depending on the time and torque of the gears tested, the test results of which are summarized in Table 2. The impact of the type of metallic dust used on the above parameters was also analyzed. It should be noted here that metallic dust was used for better heat exchange between the gear and the environmental.

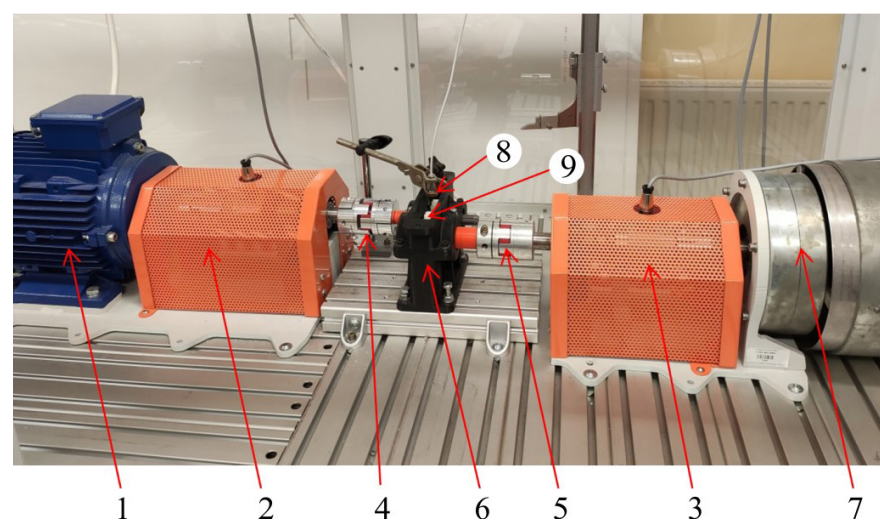

Fig. 5. Test stand: 1 - engine, 2 and 3 - torque sensors, 4 and 5 - clutches, 6 - gear housing, 7 - brake, 8 - temperature sensor, 9 - gears 


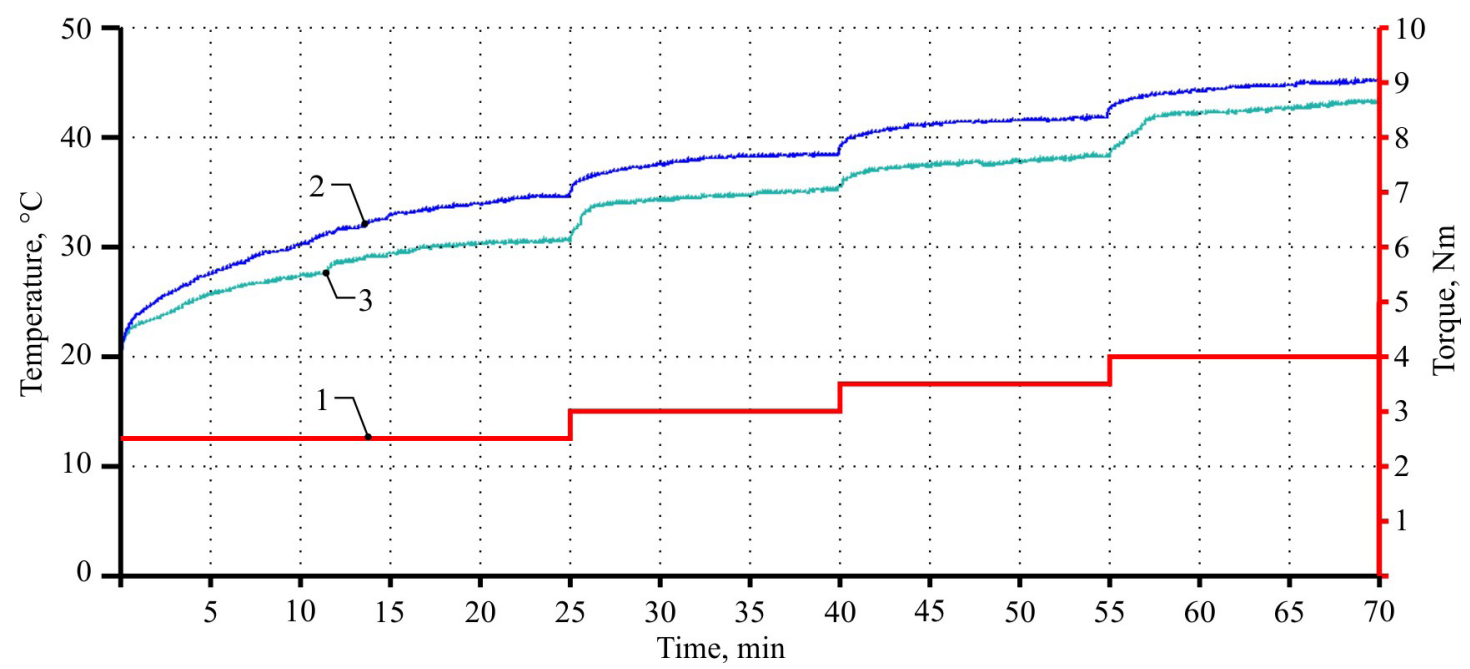

Fig. 6. Graph of temperature changes in the meshing zone depending on time and torque: 1 - tarque graph, 2 - temperature graph for involute profile gears, 3 - temperature graph for sinusoidal gears obtained from ABS composite filled with $20 \mathrm{wt} \%$ copper dust (ABS + P2)

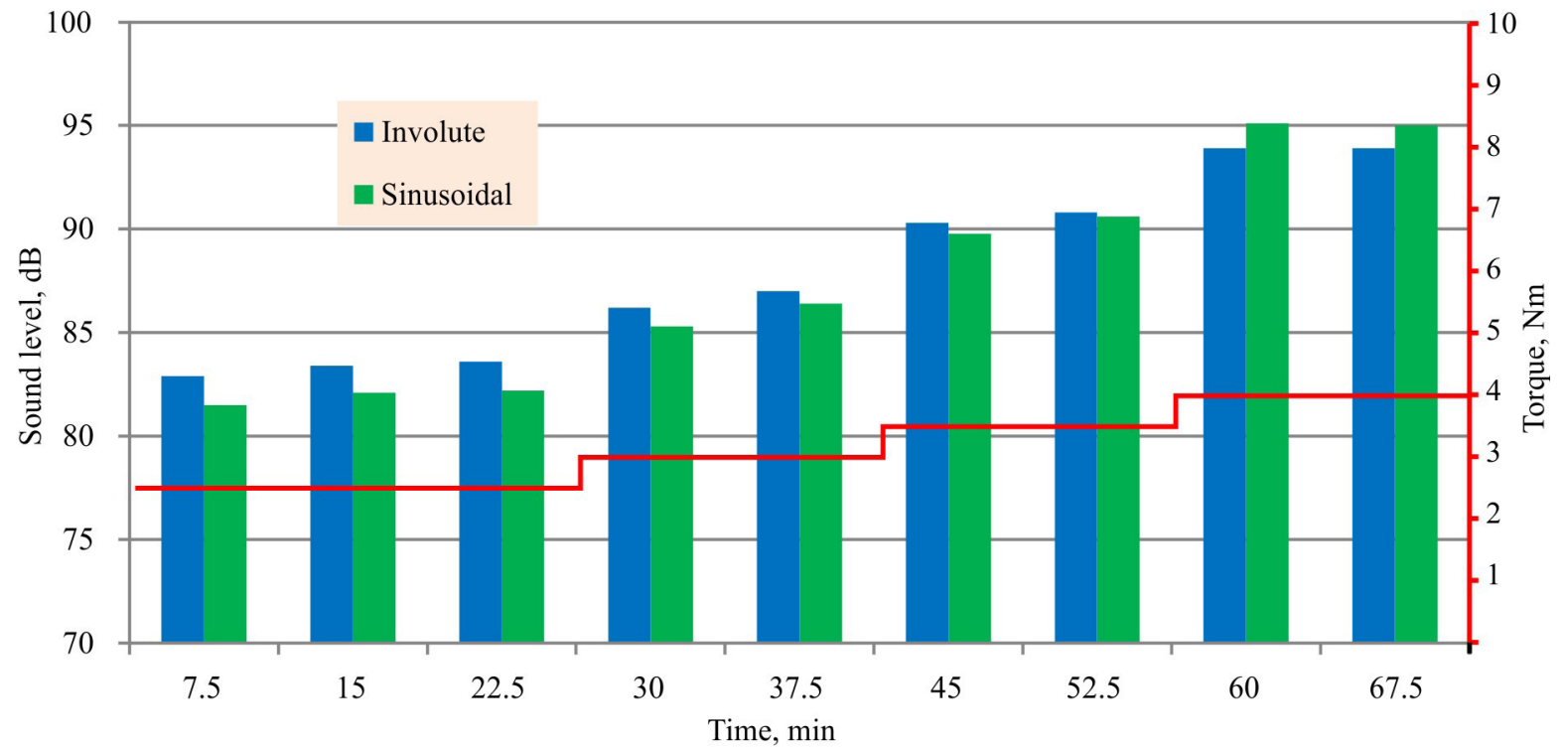

Fig. 7. Graph of changes in the sound intensity level of the meshing zone depending on the time and torque for the involute and sinusoidal gears obtained from ABS composite filled with $20 \mathrm{wt} \%$ copper dust (ABS + P2)

Based on the obtained test results (Fig. 6 and Table 2), a significant impact of the applied torsional moment on temperature increase was observed. It was also observed that the temperature of the gears with involute profiles is higher compared to gears with sinusoidal profiles (Fig. 7, Table 2). It should also be noted that the sound intensity level (Fig. 7) is lower in the range of nominal load for sinusoidal gears. Only after exceeding the nominal moment by about $30 \%$ the involute gears run quieter.
This observation allows to conclude that gears with these profiles may find wider application in the design of devices that should be characterized by low sound levels and lower operating temperature (Table 2). It was generally observed that the best test results were obtained for sinusoidal gears obtained from ABS filled with P2 cooper dust. Unfortunately, in the literature, there are virtually no publications related to the testing of machine components manufactured incrementally and loaded with 
$\mathrm{T}$ a b 1 e 2. Measurement results: temperature and sound intensity as a function of torque

\begin{tabular}{|c|c|c|c|c|c|c|c|c|c|c|c|c|c|c|c|c|}
\hline \multirow{3}{*}{$\begin{array}{l}\text { Composite } \\
\text { symbol }\end{array}$} & \multicolumn{4}{|c|}{ Temperature, ${ }^{\circ} \mathrm{C}$} & \multirow{2}{*}{\multicolumn{4}{|c|}{$\begin{array}{l}\text { Torque, } \mathrm{Nm} \\
\text { rrofile }\end{array}$}} & \multicolumn{4}{|c|}{ Temperature, ${ }^{\circ} \mathrm{C}$} & \multicolumn{4}{|c|}{ Torque, $\mathrm{Nm}$} \\
\hline & \multicolumn{4}{|c|}{ Involute profile } & & & & & \multicolumn{8}{|c|}{ Sinusoidal profile } \\
\hline & A & B & $\mathrm{C}$ & $\mathrm{D}$ & $\mathrm{A}$ & B & $\mathrm{C}$ & $\mathrm{D}$ & $\mathrm{A}$ & B & $\mathrm{C}$ & $\mathrm{D}$ & $\mathrm{A}$ & B & $\mathrm{C}$ & $\mathrm{D}$ \\
\hline ABS & 37.0 & 41.0 & 44.0 & 47.0 & 2.5 & 3.0 & 3.5 & 4.0 & 35.0 & 39.5 & 41.0 & 44.5 & 2.5 & 3.0 & 3.5 & 4.0 \\
\hline $\mathrm{ABS}+\mathrm{P} 1$ & 35.5 & 39.0 & 43.0 & 46.0 & 2.5 & 3.0 & 3.5 & 4.0 & 32.0 & 37.0 & 38.5 & 42.5 & 2.5 & 3.0 & 3.5 & 4.0 \\
\hline $\mathrm{ABS}+\mathrm{P} 2$ & 35.0 & 39.0 & 42.5 & 45.5 & 2.5 & 3.0 & 3.5 & 4.0 & 30.0 & 36.0 & 38.0 & 42.0 & 2.5 & 3.0 & 3.5 & 4.0 \\
\hline \multirow[t]{4}{*}{$\mathrm{ABS}+\mathrm{P} 3$} & 36.0 & 39.5 & 43.0 & 46.5 & 2.5 & 3.0 & 3.5 & 4.0 & 32.5 & 37.5 & 39.0 & 43.0 & 2.5 & 3.0 & 3.5 & 4.0 \\
\hline & \multicolumn{4}{|c|}{ Sound intensity level, $\mathrm{dB}$} & \multicolumn{4}{|c|}{ Torque, $\mathrm{Nm}$} & \multicolumn{4}{|c|}{ Sound intensity level, $\mathrm{dB}$} & \multicolumn{4}{|c|}{ Torque, $\mathrm{Nm}$} \\
\hline & \multicolumn{8}{|c|}{ Involute profile } & \multicolumn{8}{|c|}{ Sinusoidal profile } \\
\hline & A & B & $\mathrm{C}$ & $\mathrm{D}$ & A & B & $\mathrm{C}$ & $\mathrm{D}$ & $\mathrm{A}$ & $\mathrm{B}$ & $\mathrm{C}$ & $\mathrm{D}$ & A & B & $\mathrm{C}$ & $\mathrm{D}$ \\
\hline ABS & 84.0 & 86.5 & 91.0 & 93.5 & 2.5 & 3.0 & 3.5 & 4.0 & 81.5 & 85.5 & 91.0 & 95.5 & 2.5 & 3.0 & 3.5 & 4.0 \\
\hline $\mathrm{ABS}+\mathrm{P} 1$ & 84.0 & 87.0 & 92.0 & 94.5 & 2.5 & 3.0 & 3.5 & 4.0 & 82.5 & 86.5 & 91.5 & 96.5 & 2.5 & 3.0 & 3.5 & 4.0 \\
\hline $\mathrm{ABS}+\mathrm{P} 2$ & 83.5 & 86.5 & 91.0 & 94.0 & 2.5 & 3.0 & 3.5 & 4.0 & 81.5 & 86.0 & 91.0 & 95.0 & 2.5 & 3.0 & 3.5 & 4.0 \\
\hline $\mathrm{ABS}+\mathrm{P} 3$ & 83.5 & 86.5 & 91.5 & 94.5 & 2.5 & 3.0 & 3.5 & 4.0 & 82.0 & 85.5 & 91.5 & 95.5 & 2.5 & 3.0 & 3.5 & 4.0 \\
\hline
\end{tabular}

a torque, which is why the obtained test results could not be referred to the results presented in the world literature.

\section{SUMMARY}

Based on the literature and conducted research results, it can be stated that due to the development of an appropriate methodology for designing and manufacturing machine components manufactured additively from polymeric materials, it allows to increase the scope of application of polymer gears with both sinusoidal and involute gears. The implementation of subsequent research using the developed methodology and analysis of results will constitute the original material that can be used to develop a database of material properties and their structures as input data used for design and calculation of additive machine elements.

\section{REFERENCES}

[1] Siemiński P., Budzik G.: „Techniki przyrostowe. Druk. Drukarki 3D", Oficyna Wydawnicza Politechniki Warszawskiej, Warszawa 2015.
[2] Quan Z., Suhr J., Yu J. et al.: Composite Structures 2018, $184,917$.

http://dx.doi.org/10.1016/j.compstruct.2017.10.055

[3] Wu Y., Isakov D., Grant P. S.: "Fabrication of Composite Filaments with High Dielectric Permittivity for Fused Deposition 3D Printing, Materials", Department of Materials, University of Oxford, 2017.

[4] Oliwa R., Oleksy M., Heneczkowski M. et al.: Polimery 2017, 62, 37.

http://dx.doi.org/10.14314/polimery.2017.036

[5] Sobolak M.: "Analiza i synteza współpracy powierzchni kół zębatych metodami dyskretnymi", Oficyna Wydawnicza Politechniki Rzeszowskiej, Rzeszów 2006.

[6] Oleksy M., Budzik G., Kozik B., Gardzińska A.: Polimery 2017, 62, 3.

http://dx.doi.org/10.14314/polimery.2017.003

Received 18 II 2020 